Developmental Psychology and Society 
The figure on the cover is based on a child's drawing in Herbert Read's Education Through Art, Faber \& Faber (1943). 


\section{DEVELOPMENTAL PSYCHOLOGY AND SOCIETY}

Edited by

John Sants

Reader in Developmental Psychology, School of Cultural and Community Studies, University of Sussex 
(C) The contributors 1980

(C) Selection and editorial matter John Sants 1980

Softcover reprint of the hardcover 1st edition 1980

All rights reserved. No part of this publication may be reproduced or transmitted, in any form or by any means, without permission

First published 1980 by

THE MACMILLAN PRESS LTD

London and Basingstoke

Associated companies in Delhi Dublin

Hong Kong Johannesburg Lagos Melbourne

New York Singapore and Tokyo

\section{British Library Cataloguing in Publication Data}

Developmental psychology and society.

1. Developmental psychology

I. Sants, John

155

BF 713

ISBN 978-1-349-16333-5 ISBN 978-1-349-16331-1 (eBook)

DOI 10.1007/978-1-349-16331-1

This book is sold subject to the standard conditions of the Net Book Agreement 


\section{Contents}

Contributors vi

Introduction 1

1 The Child in Psychology 15 John Sants

2 Neurological Development and the Growth of Psychological Functions

Colwyn Trevarthen

3 The Relevance of Ethology

P. J. B. Slater

4 Some Methodological Issues in Developmental Research Harry McGurk

5 Piagetian Perspectives

Hans Furth

6 Two Decades of Research into Early Language Roger Goodwin

7 The Nature of Educational Competence

J. G. Wallace

8 The Significance of Sex Differences in Developmental Psychology

253 John Archer and Barbara Lloyd

9 Universality and Plasticity, Ontogeny and Phylogeny:

The Resonance Between Culture and Cognitive Development Neil Warren

10 Society's Cradle: An Anthropological Perspective on the Socialisation of Cognition

Billie Jean Isbell and Lauris McKee

11 Developmental Psychology and Society

John Sants

Index 


\section{Contributors}

JOHN ARCHER

School of Psychology, Preston Polytechnic, Preston, Lancashire, England HANS FURTH

The Boys Town Center for the Study of Youth Development, The Catholic University of America, Washington, USA

ROGER GOODWIN

School of Cultural and Community Studies, University of Sussex, Falmer, Brighton, Sussex, England

BILLIE JEAN ISBELL

Department of Anthropology, Cornell University, McGraw Hall, Ithaca, New York, USA

\section{BARBARA LLOYD}

School of Social Sciences, University of Sussex, Falmer, Brighton, Sussex, England

HARRY MCGURK

Department of Psychology, University of Surrey, Guildford, Surrey, England LAURIS McKEE

Department of Anthropology, Cornell University, McGraw Hall, Ithaca, New York, USA

JOHN SANTS

School of Cultural and Community Studies, University of Sussex, Falmer, Brighton, Sussex, England

P. J. B. SLATER

Ethology and Neurophysiology Group, School of Biological Sciences, University of Sussex, Falmer, Brighton, Sussex, England

COLWYN TREVARTHEN

Department of Psychology, University of Edinburgh, Edinburgh, Scotland

J. G. WALLACE

School of Education, Deakin University, Victoria, Australia

NEIL WARREN

School of African and Asian Studies, University of Sussex, Falmer, Brighton, Sussex, England 